\title{
Otel İşletmelerinde Çalışan İşgörenlerin Örgütsel Adalet Algılarının Motivasyon Ve İşten Ayrılma Niyeti Üzerine Etkisi (The Effect of Organizational Justice Perception on Motivation and Intention to Leave Work of Employee in Hotel Enterprises)
}

\section{Güngör UYSAL (iDa Ahmet TAYFUN}

a Gazi Üniversitesi, Sosyal Bilimler Enstitüsü, Ankara, Türkiye. gungoruysal92@gmail.com

b Ankara Hacı Bayram Veli Üniversitesi, Turizm Fakültesi, Ankara, Türkiye. ahmet.tayfun@hbv.edu.tr

\begin{tabular}{|c|c|}
\hline MAKALE BİLGİSİ & ÖZET \\
\hline $\begin{array}{l}\text { Anahtar Kelimeler: } \\
\text { Örgütsel Adalet } \\
\text { Motivasyon } \\
\text { İşten Ayrilma Niyeti }\end{array}$ & $\begin{array}{l}\text { Amaç - Bu çalışma insan kaynağının büyük öneme sahip olduğu otel işletmelerinde çalışan } \\
\text { işgörenlerin örgütsel adalet algısının motivasyon ve işten ayrılma niyetlerine etkisini tespit } \\
\text { etmek amacıyla yapılmıştır. Bu çalışmada, örgütsel adalet üç boyutta ele alınmıştır. Bunlar; } \\
\text { dağıtımsal adalet, işlemsel adalet ve etkileşimsel adalettir. Ayrıca çalışmada, motivasyon ve } \\
\text { işten ayrılma niyeti kavramları detaylı bir şekilde incelenmiştir. }\end{array}$ \\
\hline $\begin{array}{l}\text { Gönderme Tarihi } 1 \text { Ekim } 2018 \\
\text { Revizyon Tarihi } 10 \text { Mart } 2019 \\
\text { Kabul Tarihi } 20 \text { Mart } 2019\end{array}$ & $\begin{array}{l}\text { Yöntem - Örgütsel adalet boyutlarının otel işletmelerinde çalışan işgörenler açısından nasıl } \\
\text { algılandığı ve bu algılamalar doğrultusunda işgörenlerin motivasyonunun ve işten ayrılma } \\
\text { niyetinin nasıl etkilendiği ortaya konulmaya çalışılmıştır. Bu çalışmanın evrenini, Ankara } \\
\text { ilindeki dört ve beş yıldızlı otel işletmelerinin bütün işgörenleri oluşturmaktadır. Araştırmada } \\
\text { nicel bir teknik olan anket tekniğinden yararlanılmıstır. Çalışmanın veri toplama sürecinde, } \\
\text { işletme yöneticileriyle doğrudan görüşülerek işgörenlere uygulanması sağlanmıştır. }\end{array}$ \\
\hline $\begin{array}{l}\text { Makale Kategorisi: } \\
\text { Araştırma Makalesi }\end{array}$ & $\begin{array}{l}\text { Bulgular - Elde edilen bulgulara göre frekans, regresyon ve korelasyon analizi yapılmıştır. } \\
\text { Araştırma sonuçlarına göre örgütsel adaletin motivasyon ve işten ayrılma niyeti üzerinde bir } \\
\text { etkiye sahip olduğu bulunmuştur. Bu etkinin motivasyon üzerinde pozitif, işten ayrılma niyeti } \\
\text { üzerinde negatif bir etkisinin olduğu görülmektedir. Ayrıca motivasyon ve işten ayrılma niyeti } \\
\text { arasında ise negatif bir ilişkinin olduğu görülmüştür. }\end{array}$ \\
\hline
\end{tabular}

Tartışma - İşletmeler açısından örgüt ortamında adaletin tesis edilmesi önem arz etmektedir. Adaletin sağlandığı bir iş ortamında işgörenler yüksek motivasyon ile performans gösterecekler ve işten ayrılma niyetinde olmayacakları için asıl işlerine ve örgüte daha fazla yoğunlaşacakları vurgulanmıştır.

\begin{tabular}{|c|c|}
\hline ARTICLE INFO & ABSTRACT \\
\hline $\begin{array}{l}\text { Keywords: } \\
\text { Organizational justice } \\
\text { Motivation } \\
\text { Intention to leave } \\
\text { Hotel enterprises }\end{array}$ & $\begin{array}{l}\text { Purpose - This study was conducted in order to determine the effect of organizational justi } \\
\text { perception on the motivation and intention of leaving the workers in the hotel business whe } \\
\text { human resources are of great importance. In this study, organizational justice is discussed } \\
\text { three dimensions. These dimensions are distributed justice, operational justice and interacti } \\
\text { justice. In addition, the concepts of motivation and dismissal intention were examined in deta } \\
\text { in the study. }\end{array}$ \\
\hline $\begin{array}{l}\text { Received } 1 \text { October } 2018 \\
\text { Revised } 10 \text { March } 2019 \\
\text { Accepted } 20 \text { March } 2019\end{array}$ & $\begin{array}{l}\text { Design/methodology/approach - It has been tried to determine how organizational justi } \\
\text { dimensions are perceived in terms of the employees employed in hotel enterprises and how th } \\
\text { motivation of the workers and the intention of leaving the job are affected in accordance wi } \\
\text { these perceptions. The population of this study constitutes all employees of four and five st } \\
\text { hotel enterprises in the province of Ankara. The survey technique, which is a quantitati } \\
\text { technique, was utilized in the research. In the process of data collection, the work has bee } \\
\text { negotiated directly with the business managers and applied to the workers. }\end{array}$ \\
\hline $\begin{array}{l}\text { Article Classification: } \\
\text { Research Article }\end{array}$ & $\begin{array}{l}\text { Findings - Frequency, regression and correlation analysis were performed according to th } \\
\text { findings obtained. According to the results of the study, it was found that organizational justi } \\
\text { had an effect on motivation and intention to leave. It's seen that this effect appears to have } \\
\text { positive effect on motivation and a negative impact on intention to leave. It's also seen that the } \\
\text { was a negative relationship between motivation and intention to quit. }\end{array}$ \\
\hline & $\begin{array}{l}\text { Discussion - For enterprises, it is important to have justice in the organizational environment. } \\
\text { In a business environment where justice is provided, those who are committed will perform } \\
\text { with high motivation and are emphasized to focus more on their original affairs and } \\
\text { organization because they do not intend to leave the job. }\end{array}$ \\
\hline
\end{tabular}




\section{Giriş}

Küreselleşme ile hız kazanarak tüm işletmeleri ve yönetimlerini etkisi altına alan bilgi ve yaratıclık kavramlarının tek kaynağı olan "insan" unsuru asıl üretim faktörü olarak ön plana çıkmaktadır. İnsan unsurunun bu denli önem kazandığı günümüz işletme yönetiminde, tüm işletme yöneticileri insan kaynaklarını ve örgütlerini, içinde bulunulan küresel çağın yeni yönetim standartlarına ve anlayışlarına göre yönetmeye çalışmaktadırlar. Bu anlamda küreselleşmenin yaygınlaştı̆̆ 1990'lı yıllardan itibaren, organizasyonlar tıpkı birer canlı organizmalar gibi kabul edilerek, insan kaynakları yönetiminde örgütsel kültür ve sosyo-psikolojik araştırmalar popülerlik kazanmıştır. Böylece günümüz organizasyonlarının yönetim kalitesinin arttırılmasında ve yüksek performans sürekliliğinin sağlanmasında, işgörenlerin içinde bulundukları örgütsel süreçleri ve olayları algılayışları ile bu olaylar karşısında kendini nasıl hissettiği çok önemli bir yönetim konusu haline gelmiştir.

Sosyolog ve psikologların sıklıkla ele aldığı "örgütsel adalet" kavramı, işletme yöneticilerinin önemsediği örgütsel performans, motivasyon ve işten ayrılma niyetini etkileyen bir araç olarak görülmeye başlanmıştır. Bu anlamda insan kaynakları yöneticileri, işletmelerindeki örgütsel adaletin sağlanmasını, işgörenlerin örgütsel adalet algılarının yükseltilmesini ve iyileştirilmesini, doğrudan doğruya işletme verimliliğini arttırmanın, işgörenlerde yüksek motivasyon sağlamanın ve işten ayrılma niyetinin azalmasının önemli bir faktörü ve etkileyicisi olarak gördükleri söylenebilir.

Nitekim bu çalışmanın temel amacı, işgörenlerin örgütsel adalet algısının motivasyon ve işten ayrılma niyetlerine etkisini belirlemektir. Ankara'da otel işletmelerinde çalışan işgörenlerin adaletli davranışlar karşısında ne derece motive oldukları ve ne derece işten ayrılmaya eğilimine yöneldikleri tespit edilecektir. Örgütlerde işgörenlerin motivasyon ve işten ayrılma niyetleri üzerinde birçok faktörün etkili olduğu bilinmektedir. Birçok faktör içerisinde örgütsel adalet kavramının işgörenlerin üzerinde ne gibi etkilerinin olduğunun bilinmesi, örgütsel adaletin diğer faktörlerden ayırılan yönünün farkında olunması, adaletsizlik algısının oluşması, motivasyon seviyesinin düşmesi ve işten ayrılma niyetinin artması durumlarına karşın gerekli önlemlerin alınması işletme çalışmalarına üst düzey faydalar sağlayacağı ifade edilebilir.

\section{Örgütsel Adalet}

Genelde çevremizde olup biten olayların ne derece adil olduğunu değerlendirir ve karşı karşıya kaldığımız adaletsizliklere, farklı şekillerde tepkiler vermeye çalışırız. İnsanların günlük hayatlarında adalet algılarını değerlendirdikleri ortamlardan biri, zamanlarının büyük bir bölümünü geçirdikleri iş yerleridir. İşgörenler, iş yerinde verilen ödüllerin adaletli bir şekilde dağıtılıp dağıtılmadığı, aldıkları ücretin ne kadar adil olduğu ve yöneticilerin kendilerine ne kadar adil davrandığı konusunda kendilerine sorular sorarlar ve bu konudaki algıları sebebiyle çevrelerine karşı bazı davranış kalıpları ve kurallar geliştirirler (Irak, 2004).

Örgütsel adalet konusunun son yıllarda çok sayıda araştırmaya konu olmasının asıl nedenlerinden biri, işgörenlerin tutum ve davranışlarına olan etkisinin yüksek olmasıdır (Yürür, 2005). Bu bakımdan değerlendirildiğinde örgütsel adalet konusunun işgörenler açısından oldukça önemli olduğu vurgulanabilir. işgörenler hem çalıştıkları örgüte karşı hem de yöneticilerine karşı güven duymak isterler. Bu güvenin sağlanmasındaki en önemli araçlardan biri de işgörenlerin örgütsel adalet algılarıdır. Çünkü işgörenler örgütte çalıştıkları süre içerinde tüm işgörenler eşit bir şekilde davranılmasını beklerler. Bu beklentileri karşılandığ takdirde işgörenlerin örgüte ve yöneticilerine olan tutum ve davranışlarında olumlu gelişmeler gözlenebilir (İçerli, 2010). Adil algılamaların işgörenlerin örgütlerine karşı olumlu bir davranış şekli oluşturacağı düşüncesi örgütsel adalet araştırmalarının artmasında itici güç olmuştur (Çolak ve Erdost, 2004).

Birçok araştırmacı tarafından adaletin farklı boyutlarını içeren, oldukça geniş bir örgütsel adalet tanımı yapılmıştır. Örgütsel adalet iş yerinde adaletin, bireye ve örgüte olan etkilerini ortaya çıkarmaya yarayan bir kavram (Karademir ve Çoban, 2010), kişinin çalışma arkadaşları, üstleri ve kurumla olan ilişkileri açısından algılamalarını içeren bir sosyal sistem (Beugre ve Baron, 2001) olarak tanımlanmıştır. Moorman örgütsel adaleti, "örgütlerde adil davranılıp davranılmadığına işgörenlerin nasıl karar verdiği ve bu kararların işle ilgili diğer durumları nasıl etkilediğiyle ilgili bir kavramdır" şeklinde tanımlamaktadır (Moorman, 1991). Örgütsel adalet, örgütün ekonomik değerlerinin örgüt içi paylaşımında adil olmanın yanında örgütte uygulanan yönetimin, stratejinin ve politikaların da adil ve tarafsız olmasıdır. İşgörenler ve yöneticiler arasında karşılıklı ilişkilerin kurulması, geliştirilmesi ve kalıcılığın işgörenler arasında ayrım gözetmeksizin 


\section{G. Uysal - A. Tayfun 11/1 (2019) 597-611}

gerçekleştirilmesidir (Cremer, 2005). Örgüt içerisinde işgörenlerin iş tutumlarını etkileyen örgütsel adalet, bireyin organizasyon içerisinde iş bölümü, ücret ve dinlenme koşullarını içerisinde barındırmasının yanında, örgüt içerisindeki sosyal etkileşim kalitesini belirleyen temel yapı olarak tanımlanmaktadır (Dinç ve Ceylan, 2008).

Örgütsel adalet algısı, bireyin gerçekte kendisine nasıl ve ne ölçüde adaletli davranıldığından çok, kendisinin bu davranışı ne ölçüde adaletli olarak algıladığına odaklanmaktadır (Taşkıran, 2011). Genel anlamda eşit konumdaki insanlara eşit davranmayı kapsayan adalet kavramı, örgütsel boyutta incelendiğinde, işgörenlere örgüte katkıları oranında haklarının, kurallara aykırı davranmaları oranında da ceza verilmesi süreci olarak tanımlanabilir (Aykut, 2007). Örgütsel adalet kavramı, bireylerin örgütteki adalet sezgilerinin tümüdür ve bu nedenle örgütün bir üyesinin algısına göre son derece adil olan bir uygulama, bir başkasına adil gelmeyebilmektedir (Atalay, 2010). Kendilerine adil davranıldığını hisseden işgörenler, pozitif davranışlar sergileyip, kendilerini örgütün değerli ve saygın birer üyesi olarak görürler. Ekip arkadaşları ve işletme yöneticileriyle güvenli ilişkiler içerisinde bulunurlar. Çalışma ortamında adaletsizlik olduğunu hisseden işgörenler (Berber, 2010), örgütlerin hedeflerine ulaşmasını engelleyen hırsızlık, saldırganlık, intikam alma gibi (Abbasoğlu, 2015), işletmeyi zarara uğratmaya yönelik birtakım olumsuz davranışlar gösterebilmektedirler (Cihangiroğlu ve Yılmaz, 2010).

Örgütlerde adalet, kazanımların dağıtılmasıyla ilgili kararların alınmasında kullanılan prosedürler ve bireyler arasındaki etkileşimin sonucu ortaya çıkan kurallar ile ifade edilmektedir. Bu kavram ile birlikte, kazanımların (dağıtım adaleti), süreçlerin (işlem adaleti) ve kişiler arası ilişkilerin (etkileşim adaleti) adilliğine dayanan boyutlar meydana gelmiştir (Serinkan, 2008). Örgütsel adalet boyutları arasında geliştirilen ilk boyut olan ve örgütsel adaletin gerçek başlangıcını oluşturan dağıtımsal adalet; işgörenlere örgütün sunduğu kazanımları ile işgörenlerin işletmedeki sorumluluklarını, işteki uzmanlıklarını, gösterdikleri çabanın miktarını ve işle ilgili diğer katkılarını karşılaştırmaktadır (Moorman, 1991). Dağıtım adaleti, kısaca örgütte çıtıların dürüstçe paylaşılmasıdır (Lambert, Hogan ve Griffin, 2007). Dağıtım adaleti, görevler, fırsatlar, cezalar, mallar, hizmetler, örgüt içerisinde aldıkları eğitim, ödüller, roller, statüler, ücretler, vb. her türlü kazanımın örgüt çalışanları arasındaki dağılımını konu alan bir kavramdır ve çalışanların kazanımların adilliğine ilişkin algılamalarını ifade etmektedir (Çağ, 2011). Foa ve Foa'nın 1974 yılında tanımladıkları altı kaynak vardır. Bunlar: hizmetler, sevgi, mallar, statü, bilgi ve paradır. Dağıtım adaleti içerisinde yer alan kaynaklar arasında en sık konu olanlar para ve mallardır. Dağıtım adaletinde önemli olan, işgörenlerin dağıtılan kaynaklardan adil şekilde pay aldığını düşünmesidir (Özen, 2002; Özdevecioğlu, 2004 ve Yürür, 2009).

Dağıtımsal adaleti ekonomik değer taşıyan kazanımların yanında sembolik kazançlara da önem vermektedir. Örneğin, işgörenlerin kendilerine prestijli ofis verilmemesi nedeniyle eşitsizlik duygusu yaşadıklarını ve bu durumun adaletsizlik algısını meydana getireceğini ifade etmiştir. Bireylerin ekonomik kazançlara bu kadar önem vermesinin nedeni ücret, sosyal statü elde etme, kendine güven duygusu yaratma ve rahatlik anlamına gelmesinden kaynaklanmaktadır (Yürür, 2005). Dağıtımsal adalet, örgütsel kaynakların dağıtımında gösterilen dürüstlük ve doğrulukla ilgilidir. Örgütlerde bireyler dağıtım adaletsizliği algilarlarsa, bu onların performanslarına, motivasyonlarına, iş tatminlerine, işletmede kalma veya ayrılma kararlarına yansır. Kaynakların adil dağıtımı yanında, ödül ve cezanın hak edene hak ettiği şekilde verilmesi de dağıtım adaletinin algılanmasında önemlidir (Özdevecioğlu, 2004).

Dağıtımsal adalet daha çok kararlarla ilgili sonuçların adil olarak algılanması ile ilgiliyken; prosedürel adalet işgörenlerin karar alma sürecine katılmaları ve karar alma sürecindeki tarafsızlık ya da objektiflikle ilgili algılarına işaret etmektedir (Moon, Kamdar, Mayer ve Takeuchi, 2008). Bir kazanımın adil olması bu kazanıma ulaşmak için izlenen yolların adil olduğu anlamına gelmez. Yöneticiler kararlara ulaşırken de adil olmalıdırlar (Lambert, 2006. Ayrıca işgörenler kazanımların adil olmadığı durumlarda prosedürel adalete daha fazla hassasiyet göstermekte olduklarına değinmişlerdir (Ambrose, 2000). Prosedürel adalet, çıtıların dağıtılması için kullanılan yöntemlerin adil olarak algılanması anlamına gelmektedir (Beugre ve Baron, 2001). İşlem, usul ve süreç adaleti olarak ifade edilen prosedürel adalet, "ücret, terfi, maddi olanaklar, çalışma şartları ve performans değerlendirmesi gibi unsurların belirlenmesi ve ölçümünde kullanılan metot, prosedür ve politikaların adil olma derecesi" olarak adlandırılmaktadır (Greenberg,1990). Prosedürel adalet kavramı, "örgütte herkese yönelik olarak aynı prosedürün izlenmesi, iş görenlerin kararlara katılma imkanının olması ve bilgilendirme sisteminin olması" anlamına gelir (Yavuz, 2010). Prosedürel adaleti 


\section{G. Uysal - A. Tayfun 11/1 (2019) 597-611}

algısının yüksek olması örgüt üyelerine değer verildiği anlamı katmaktadır (Niehoff ve Moormon,1993). İşgörenler süreçlerin adil olmadığı duygusuna kapıldıklarında kazanımlarının olumsuzluğu ve işgörenlerin tepkileri arasında güçlü bir ilişki olduğu görülmektedir. Bu durumda işgörenler, yöneticilerine daha az bağlı olmakta, hırsızlık, sinik davranışlar, bireyin çıarına yönelik politik etkileme taktikleri gibi daha çok verimliliğe ve çalıştıkları işletmeye zarar veren davranışlarda bulunmakta, işten ayrılma niyetlerinde artış olmakta ve performanslarında düşme, örgüte ve yöneticilerine olan güveni azaltmaktadır (Yıldırım, 2006).

Etkileşimsel adalet diğer adalet türlerinden farklı olarak insanın olduğu her yerde olması gereken yöne bakar ve örgütsel adaletin sosyal yönünü ele almaktadır. Etkileşimsel adalet, çalışanlar ve yöneticiler arasındaki ilişkide adaletin sağlanmasında maddi unsurların dışında, örgütsel adaletin sosyo-psikolojik yönüyle ilgilenmekte ve örgütün şeffaf olması yönünde çaba sarf etmektedir. Bu durumda etkileşim adaletinin işleyişinde bilgi paylaşımının önemli olduğu akıldan çıkarılmamalıdır (Kılıçlar, 2011). Ayrıca örgüt içindeki ilişkilere yapılan yatırımın ve sonucunda meydana gelecek olan çıktıların üzerinde durmaktadır. Etkileşimsel adalet, örgütlerde karar alma süreçlerinin yürütülmesinde adaletin sağlanmasına yönelik yönetsel sorumluluklar olarak tanımlanmaktadır (Arslantaş ve Dursun, 2008). Etkileşimsel adaletin yüksek olduğu durumlarda, işgörenler açısından dağıtımsal ve prosedürel adaletin öneminin azaldığı ve kesişimin anlamlı olmadığı belirtilmektedir. Ulaşılan bulgular neticesinde, işverenlerin işgörenlere karşı duyarlı, ilgili, saygılı ve itibarlı davranışlar sergilediklerinde, işgörenlerin adaletsiz ücret dağılımını veya adaletsiz süreçleri bir nebze görmezden gelmeleri, daha fazla hoşgörülü olma yönünde hareket ettikleri, şeklinde yorumlanmıştır (Laçinoğlu, 2010).

\section{Motivasyon}

Modern organizasyonlarda yöneticiler motivasyon konusu ile yakından ilgilenmek durumundadırlar. Zira yöneticilerin başarısı, astların organizasyonun amaçları doğrultusunda çalışmasına, bilgi yetenek ve becerilerini tam olarak bu yönde harcamalarına bağlıdır. Bir diğer ifadeyle motivasyon ile işgörenlerin performansı arasında doğrusal bir ilişki bulunmaktadır. Teşvik edilmeyen işgörenlerin yüksek performans göstermesi beklenemez. İşgörenler çok çeşitli davranışlar sergileyebilirler. Bu davranışların farklı nedenleri olabilir. Yönetici bakımından önemli olan işgörenlerin organizasyonun amaçları yönünde hareket etmelerinin sağlanabilmesidir. Bu bağlamda, sürdürülebilir rekabet avantajı sağlamada işgörenlerin motivasyon düzeyleri önemli bir role sahiptir. İnsan emeği, diğer üretim faktörleriyle birleşerek işletmenin amaçlarına katkıda bulunur. İş yaşamının kritik ve kaotik bir görünüm arz ettiği sanayi-ötesi çağda, işgörene iş ortamını ve çalışmayı benimsetmek ve bu doğrultuda örgütsel performansı arttırmaya çalışmak, yöneticilerin en öncelikli konuları arasındadır (Öğüt, Akgemici ve Demirsel, 2004).

Motivasyonu kişilerin belirli bir amacı gerçekleştirmek üzere kendi arzu ve istekleri ile davranmaları ve çaba göstermeleri şeklinde tanımlamak mümkündür (Koçel, 2011). Motivasyon konusu esas itibariyle kişilerin bekleyiş ve ihtiyaçları, amaçları, davranışları, kendi performansları hakkında bilgi verilmesi konuları ile ilgilidir. Dolayısıyla motivasyon sürecini tam olarak kavrayabilmek için kişileri belirli şekillerde davranmaya zorlayan nedenleri, kişinin amaçları ve davranışların sürdürülme olanakları gibi konuların incelenmesi gerekmektedir (Koç ve Topaloğlu, 2012). Motivasyon, bireyleri kişisel ihtiyaçlarının tatmin edileceğine inandırarak, onları örgütsel amaçlar doğrultusunda çaba göstermeye isteklendirme sürecidir. Motivasyon, örgütün ve bireylerin ihtiyaçlarını karşılayacak bir iş ortamı oluşturmak maksadıyla bireyin harekete geçmesi için etkilenmesi ve teşvik edilmesi sürecidir. Bir hareketin yönü, şiddeti ve devamlıllğı üzerine çabuk ve derhal yapılan etkidir (Küçükahmet, 2001). Motivasyon yönlendirici bir güç olarak bilinir. Kişiyi bir hedef doğrultusunda ileriye taşımak, yönlendirmek kısacası harekete geçirmek için kullanılan bir araçtır (Bakan, 2011). Motivasyon örgütlerin etkinliği ile doğrudan ilişkilidir ve süreklilik gösterdiği müddetçe etkinliği süreceğinden yöneticiler açısından çalışanlarını motive edici gayretler devamlılık göstermek zorundadır. Bu açıdan, motivasyon yöneticiler için bir nevi yol gösterici olmaktadır (Akbudak, 2013). Motivasyon, işe devam, iş yöntemlerinin geliştirilmesi ve iş ortamındaki işbirliğinin arttırılması gibi alanlarda davranışların temel nedeni olarak tanımlanmaktadır (Sökmen, 2010).

Motive olmamış personel, yaptığı işe gereken önemi vermeyecektir. Bu da kurum açısından hem zaman kaybına hem de maddi kayıplara neden olacaktır. Bir işgöreni motive eden herhangi bir olay, başka bir işgöreni motive etmeyebilir. Kimileri para ile motive olurken kimileri de destek ile motive olurlar. İşte yöneticiler, iş görenler üzerindeki bu farklılığı tespit ederek işgörenleri motive edebilirler (Çelik, 2011). Diğer 
yandan işgörenlerin işinde motive olmaması ya da az motive olmasının hem işgörenler hem de örgütler açısından bazı önemli sonuçları vardır (Efil, 2010). Şöyle ki; örgütsel motivasyon seviyesi yüksek olan işgörenler, işteki pozisyonlarının gerektirdiği işlerin ötesinde görevlerini en iyi biçimde yapabilmek için çaba gösterirlerken, örgütsel veya iş motivasyonu düşük olan bireyler ise, günlük ve örgütsel hayatlarında olumsuz davranışlar sergilemektedirler (Sökmen, 2010). Örneğin, örgütsel motivasyonu düşük olan bir işgörende, fiziksel olarak geri çekilme, verimde düşme, konsantrasyonda azalma, hatalarda artış, hoşgörüde azalma, duyarsızlıklar, kişilerarası ilişkilerde çatışmalar ve hatta saldırganlık gibi olumsuz davranışlar kendini göstermektedir (Bilsel, 2013).

Günümüz küresel iş dünyasında bütün işletmelerin başarısı, işgörenlerin hedeflerine olan bağlılıklarına ve bu hedefler doğrultusundaki çabalarına bağlıdır. Çalışma isteği yeterli seviyede olmadıkça başarı sağlamak ve örgütün amaçlarını gerçekleştirmek zorlaşmaktadır (Bakan, 2011). Bu nedenle artık yöneticiler her düzeydeki elemanlarının verimini arttırmayı, düşünsel ve bedensel rasyonelliği ön plana çıarmayı amaçlamaktadır. Özellikle yönetim uygulamaları ile bir yandan işgörenlerin mutluluğu arttrrılmak istenmekte, diğer yandan rasyonellik sınırları içinde üretkenlik desteklenmektedir. Çalışma yaşamı içerisinde günlük yaşantısının büyük bir kısmını iş ortamında geçiren kişinin olanaklar ölçüsünde, iş tatminsizliği, hayal kırıklığı gibi duygusal sorunlardan uzak tutulması, buna karşılık iş tatminin arttırılması gerekir (Karaboğa, 2007).

\section{İşten Ayrilma Niyeti}

İşten ayrılma niyeti en genel anlamı ile işgörenlerin iş koşullarından tatminsiz olmaları halinde göstermiş oldukları yıkıcı ve aktif olan eylem olarak tanımlanabilmektedir. İşten ayrılma niyetinin kurumsal etkinliği olumsuz yönde etkiliyor olması konuyu yöneticiler açısından oldukça önemli kılmaktadır. İşten ayrılma niyeti kavramı psikoloji, sosyoloji ve örgütsel davranış gibi farklı disiplinlerin incelediği bir konudur. Bunun nedeni çalışmalarda işten ayrılma niyetinin kurumsal etkinlik üzerindeki olumsuz etki oluşturduğuna ilişkin bulgulardır. İşten ayrılma niyeti günümüzde çok önemli olan kurumsal bilgi, kültür, yetenek ve doğal olarak entelektüel sermayenin kaybı, yeniden işe almanın getirdiği oryantasyon ve eğitim maliyeti gibi birçok olumsuz sonuç doğurmaktadır (İşçi, 2010).

İşten ayrılma, bireyin örgütün aidiyet sınırlarının ötesine geçme hareketidir. Bir örgütü terk etme örgütten belirli bir zamanda fiziksel olarak ayrılma durumudur şeklinde tanımlanmış ve zaman unsuru da ön plana çıkarılmıştır (Kaya, 2012). İșten ayrılma niyeti; düşünme, planlama ve işten ayrılmayı isteme olarak sıralanan bilişsel bir süreçtir (Lambert, 2006). Başka bir ifadeyle bu kavram, herhangi bir girişim ile işe son verilmesi düşüncesi olarak tanımlanabilmektedir (Kaya ve Abdioğlu, 2010). İşten ayrılma niyeti, işgörenlerin işin sahip olduğu şartlardan tatmin olmamaları durumunda göstermek istedikleri yıkıcı ve aktif faaliyetlerdir (Erbil, 2013). Bir diğer tanıma göre işten ayrılma niyeti, işgörenlerin mevcut iş koşullarından duymuş oldukları memnuniyetsizlik dolayısıyla işlerinden ayrılmayı düşünmeleri olarak da ifade edilmektedir (Özcan, Vardarlıer, Karabay, Konakay ve Çetin, 2012). İşten ayrılma niyeti, örgütten ayrılmak için kasıtlı ve bilinçli bir istek olarak tanımlanmakta ve işten ayrılma davranışının en önemli belirleyici unsuru veya göstergesi olarak ifade edilmektedir (Tett ve Meyer, 1993).

Geçtiğimiz otuz yıl içerisinde özellikle işgören devrinin finansal etkilerine yönelik araştırmaların daha da arttığ1 gözlenmektedir (Porter, Steers ve Boulian, 1973; Çekmecelioğlu, 2005; Avcı ve Küçükusta, 2009; Solmaz, 2010). Bunun asıl sebebi işgörenlerin yetiştirilmesi için harcanan para ve zaman işletmeler için önemli bir maliyet unsurudur. Bu yüzden de işten ayrılma niyeti dikkate alınması gereken bir konudur. İşten ayrılma niyetine sahip bir işgörene eğer müdahale edilmezse zaman içerisinde bu düşünce işten ayrılmaya dönüşmektedir. İşten ayrılma gerçekleştikten sonra da artık bunu geri döndürmek oldukça zor ve hatta mümkün olmamaktadır. Fakat işten ayrılma niyeti içerisinde olan işgörenlere gerekli önlemler alınarak işte kalması sağlanabilir (Yıldız, 2008).

\section{Yöntem}

\section{Araştırmanın Modeli}

Örgütsel adaletin alt boyutları olan dağıtımsal adalet, işlemsel adalet ve etkileşimsel adalet işgörenlerin işten ayrılma niyetlerini ve motivasyonlarını farklı düzeylerde etkilemektedir. Bu doğrultuda araştırmanın modeli geliştirilerek aşağıdaki şekilde gösterilmiştir: 


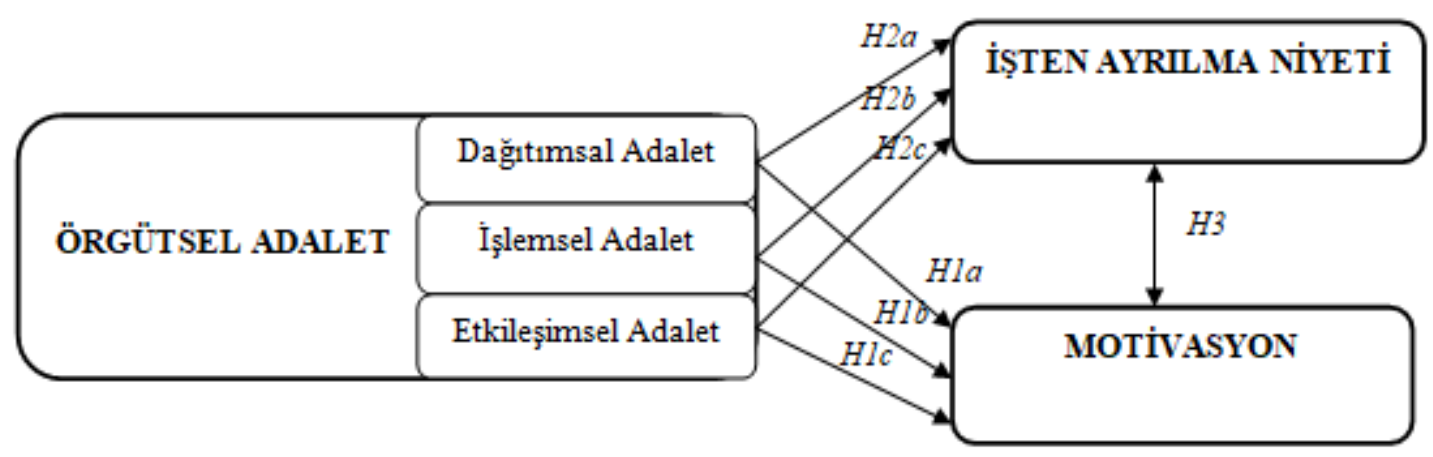

Şekil 1. Araştırmanın Modeli

Modelde bulunan oklar, kutucuklarda yazan kavramların arasındaki etkiyi ve ilişkiyi göstermektedir. Bu noktada oluşturulan hipotezler ise şu şekildedir:

H1: Örgütsel adalet algısının işgören motivasyonu üzerinde etkisi vardır.

$H_{11 a}$ : Dağıtım adalet algısının işgören motivasyonu üzerinde etkisi vardır.

$\mathrm{H}_{1 \mathrm{~b}}:$ İşlemsel adalet algısının işgören motivasyonu üzerinde etkisi vardır.

Hıc: Etkileşimsel adalet algısının işgören motivasyonu üzerinde etkisi vardır.

$\mathbf{H}_{2}$ : Örgütsel adalet algısının işgörenlerin işten ayrılma niyeti üzerinde etkisi vardır.

$\mathbf{H}_{2 a}$ : Dağıtım adalet algısının işgörenlerin işten ayrılma niyeti üzerinde etkisi vardır.

$\mathbf{H}_{2 b}$ :İşlemsel adalet algısının işgörenlerin işten ayrılma niyeti üzerinde etkisi vardır.

$\mathbf{H}_{2}$ : Etkileşimsel adalet algısının işgörenlerin işten ayrılma niyeti üzerinde etkisi vardır.

$\mathbf{H}_{3}$ : İşgören motivasyonu ile işten ayrılma niyeti arasında anlamlı bir ilişki vardır.

\section{Evren ve Örneklem}

Araştırma evrenini, Ankara'da faaliyet gösteren dört ve beş yıldızlı otel işletmelerinde çalışan işgörenler oluşturmaktadır. Kültür ve Turizm Bakanlığının Turizm İşletme Belgeli Tesislere ilişkin verilerine göre Ankara' da 48 tane dört yıldızlı, 23 tane beş yıldızlı otel işletmesi bulunmaktadır. Bu otellerde çalışan toplam kişi sayısına ulaşmak için ise şu formül kullanılmaktadır (Erdem, 2002):

Personel Sayısı

Oda Başına Düşen Personel Sayısı =

\section{Oda Sayıs1}

Türkiye' de oda başına düşen personel sayısı; 4 yıldızlı otellerde 0.76 ve 5 yıldızlı otellerde 1.18 kişi olarak belirtilmektedir (Ağaoğlu, 1992). Ankara'da bulunan 4 yıldızlı otellerin toplam oda sayısı 3435, 5 yıldızlı otellerin oda sayısı ise 4792 'dir. Bu veriler neticesinde 4 yıldızlı otellerde toplam 2610 kişi çalışması gerekirken, 5 yıldızlı otellerde ise 5654 kişi çalışması gerekmektedir. Araştırma çalışmasının evreninin toplamı 8264 kişiden oluşmaktadır.

Örneklem hatasının 0.05 olduğu ve evrendeki kişi sayısının 10000 olarak kabul edildiği araştırmalarda örneklem sayısının en az 370 kişi olması beklenmektedir (Yazıcıoğlu ve Erdoğan: 2004). Otellerin departman yöneticileri ve insan kaynakları departmanları ile yapılan görüşmeler sonucunda, araştırma çalışmasının yapılmasına izin veren otellerin işgörenlerine, kolayda örnekleme yöntemiyle anketler uygulanmışır. Toplam 411 tane katılımcıya ulaşılmış, bunların 393 tanesi kullanıma uygun olarak analize tabi tutulmuştur. Bu durumda elde edilen örneklem sayısının yeterli olduğu söylenebilir.

\section{Veri Toplama Teknikleri}

Araştırmaya veri toplamak amacıyla anket tekniğinden faydalanılmıştır. Anket formu, literatür taraması sonucu elde edilen daha önce kullanılmış güvenilirliği ve geçerliliği kanıtlanmış konuyla ilgili ölçeklerden faydalanılarak tasarlanmıştır. Anket formu dört bölümden oluşmaktadır. İlk bölümde, demografik özelliklere ilişkin sorular yer almaktadır. İkinci bölümde, örgütsel adalet algılarını belirlemeye ilişkin ifadeler yer almaktadır. Üçüncü bölümde işten ayrılma niyetine yönelik ifadeler yer almaktadır. Son bölümde ise motivasyon düzeylerini belirlemeye ilişkin sorulardan oluşmaktadır. 


$$
\text { G. Uysal - A. Tayfun 11/1 (2019) 597-611 }
$$

Örgütsel adalet algılarını belirlemek için, Niehoff ve Moorman (1993) tarafından geliştirilen, 20 ifadeden oluşan örgütsel adalet ölçeği kullanılmış, bu ölçek ile katılımcıların dağıtımsal adalet, işlemsel adalet ve etkileşimsel adalet boyutları ayrı ayrı belirlenmiştir (Laçinoğlu, 2010). Örgütsel adalet ölçeğinin güvenirlik analizi sonuncunda elde ettiği Croanbach Alpha iç tutarlılık katsayısı ölçeğin bütünü için 0.96 olarak tespit edilmiştir. Bu araştırmada aynı ölçek için uygulanan güvenirlik analizi sonucunda Cronbach Alpha iç tutarlılık kat sayısı dağıtımsal adalet boyutunda 0.88, işlemsel adalet boyutunda 0.85, etkileşimsel adalet boyutunda 0.92 ölçeğin tamamında ise 0.94 olarak tespit edilmiştir. İşten ayrılma niyetini belirlemek için, Demirel (2012)'in çalışmasında kullandığı 3 ifadeden oluşan işten ayrılma niyeti ölçeği yer almaktadır. Ölçeğe uygulanan güvenirlik analizi sonucunda, Cronbach Alpha iç tutarlılık kat sayısı 0.87 olarak bulunmuştur. Motivasyon düzeylerinin belirlemek için, Gökkaya (2012)'nın çalışmasında kullandığı 23 ifadeden oluşan motivasyon ölçeği yer almaktadır. Belirtilen 23 ifade motivasyon araçlarından meydana gelmektedir. Ölçeğin Cronbach Alpha iç tutarlılık kat sayısı 0.92 olarak bulunmuştur.

\section{Verilerin Analizi}

$\mathrm{Bu}$ araştırmada toplanan verilerin analizinde sosyal bilimlerde yaygin olarak kullanılan istatistik paket programı, SPSS 22.0 kullanılmıştır. Araştırmada, değişkenler arasındaki etkiyi belirlemek için regresyon, ilişkiyi belirlemek için ise korelasyon analizi yapılmıştır.

\section{Bulgular ve Yorum}

Bu bölümde, ilk olarak araştırmaya katılan işgörenlerin demografik özelliklerine, ardından regresyon ve korelasyon analizlerinin sonuçları, yorumları ve araştırma hipotezlerinin kabul edilip edilmediğine yer verilmiştir.

\section{Demografik Bulgular}

Anket çalışması sonucu elde edilen demografik bulgular aşağıda yer alan çizelge ile ayrıntılı bir şekilde gösterilip, yorumlanmıştır. Demografik bulgular şu şekilde dağılım göstermektedir;

Tablo 1. İşgörenlerin demografik ve diğer bireysel özelliklerine ilişkin bilgiler

\begin{tabular}{llrc}
\hline \hline \multirow{2}{*}{ Bireysel Değişkenler } & & $\mathbf{F}$ & \% \\
\hline \hline \multirow{3}{*}{ Cinsiyet } & Kadın & 100 & 25,4 \\
& Erkek & 293 & 74,6 \\
& Toplam & 393 & $\mathbf{1 0 0}$ \\
\hline \hline \multirow{4}{*}{ Yaş } & 20 ve Altı & 20 & 5,1 \\
& $21-25$ & 99 & 25,2 \\
& $26-30$ & 116 & 29,5 \\
& $31-35$ & 64 & 16,3 \\
& $36-40$ & 44 & 11,2 \\
& 41 ve Üstü & 50 & 12,7 \\
& Toplam & 393 & $\mathbf{1 0 0}$ \\
\hline \hline \multirow{3}{*}{ Eğitim Durumu } & İlköğretim & 62 & 15,8 \\
& Lise & 137 & 34,9 \\
& Önlisans & 65 & 16,5 \\
& Lisans & 124 & 31,6 \\
& Lisansüstü & 5 & 1,3 \\
& Toplam & 393 & $\mathbf{1 0 0}$ \\
\hline \hline \multirow{3}{*}{ Medeni Durum } & Bekar & 200 & 50,9 \\
& Evli & 180 & 45,8 \\
& Boşanmış & 13 & 3,3 \\
& Toplam & 393 & $\mathbf{1 0 0}$ \\
\hline \hline
\end{tabular}

Katılan işgörenlerin, \% 25,4 kadınlardan, \%74,6 erkeklerden oluşmaktadır. Bu sonuca göre katılımcıların büyük çoğunluğunun erkek olduğu görülmektedir. Yaş aralıkları incelendiğinde, \%5,1'i 20 yaş ve altı, \%25,2'si 21-25 yaş arası, \%29,5'i 26-30 yaş arası, \%16,3'ü 31-35 yaş arası, \%11,2'si 36-40 yaş arası ve son 
olarak \%12,7'si 41 yaş ve üstü işgörenlerden oluşmaktadır. 21-25 yaş grubu ile 26-30 yaş grubu kişilerin ağırlıklı olduğu görülmektedir. Bu durumda genç yaştaki çalışanların çoğunlukta olduğu sonucuna ulaşılabilir. Eğitim durumları dağılımına bakıldığında, çalışanların \%15,8'i ilköğretim, \%34,9'u lise, \%16,5'i önlisans, \%31,6'sı lisans, \%1,3'ü lisansüstü mezunu oldukları görülmektedir. İşgörenlerin çoğunun lise ve lisans mezunu olmaları eğitimli ve eğitim seviyelerinin iyi seviyede olduğunu ifade etmektedir. Araştırmaya katılanların \%50,9'u bekar, \%45,8'i evli, \%3,3'ü boşanmış kişilerden oluşmaktadır.

\section{Hipotezlerin Test Edilmesi}

Çalışmanın bu bölümünde araştırma hipotezleri test edilmiştir. Bu kapsamda otel işletmelerinde çalışan işgörenlerin örgütsel adaletin alt boyutları olan; dağıtımsal adalet, işlemsel adalet ve etkileşimsel adaletin işten ayrılma niyetine ve motivasyona olan etkileri, bunun yanında motivasyon ile işten ayrılma niyeti arasındaki ilişki incelenmiştir.

Hı: Örgütsel adalet algısının işgören motivasyonu üzerinde etkisi vardır.

Hı:Dağıtımsal adalet algısının işgören motivasyonu üzerinde etkisi vardır.

Tablo 2. Dağıtımsal Adalet Algısının Motivasyon Üzerinde Etkisi

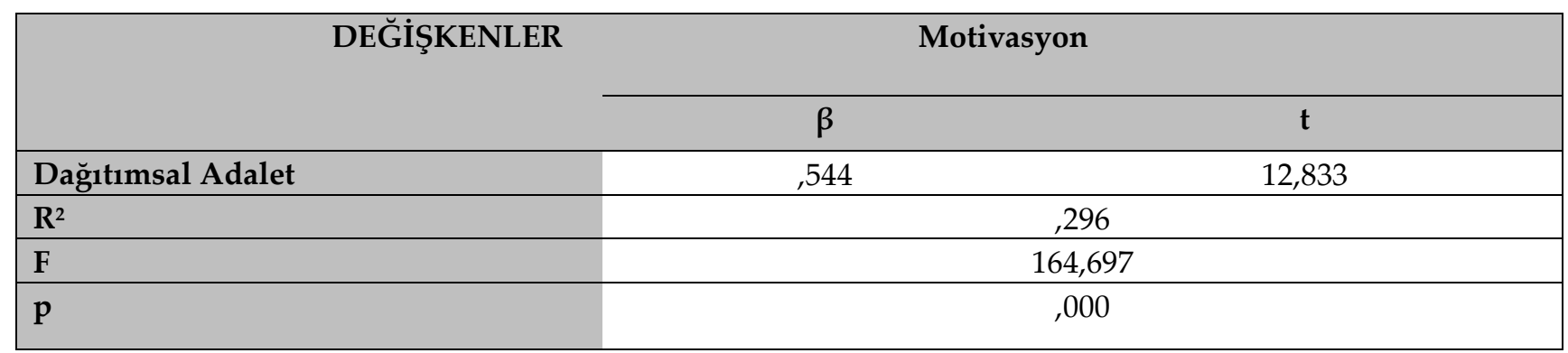

${ }^{*} \mathrm{p}<0,05$ anlamlı ilişki

Tablo 2'de görüldüğü gibi, $\mathrm{R}^{2}=, 296 ; \mathrm{F}=164,697 ; \mathrm{p}=, 000$ olduğu için regresyon modeli istatistiksel olarak anlamlıdır. Dağıtımsal adalet algısı motivasyon üzerinde \%29,6 etkiye sahiptir. Ayrıca dağıtımsal adalet, motivasyon üzerinde bir etkiye sahiptir. $t$ değerine bakıldığında etkinin istatiksel olarak anlamlı ve pozitif olduğu görülmektedir $(\beta=, 544 ; \mathrm{t}=12,833 ; \mathrm{p}=, 000)$. Buradan hareketle $\mathrm{H}_{1 a}$ yeterli kanıtla desteklenmiştir.

$\mathbf{H}_{1 \mathrm{~b}}$ :İşlemsel adalet algısının işgören motivasyonu üzerinde etkisi vardır.

Tablo 3. İşlemsel Adalet Algısının İşgören Motivasyonu Üzerinde Etkisi

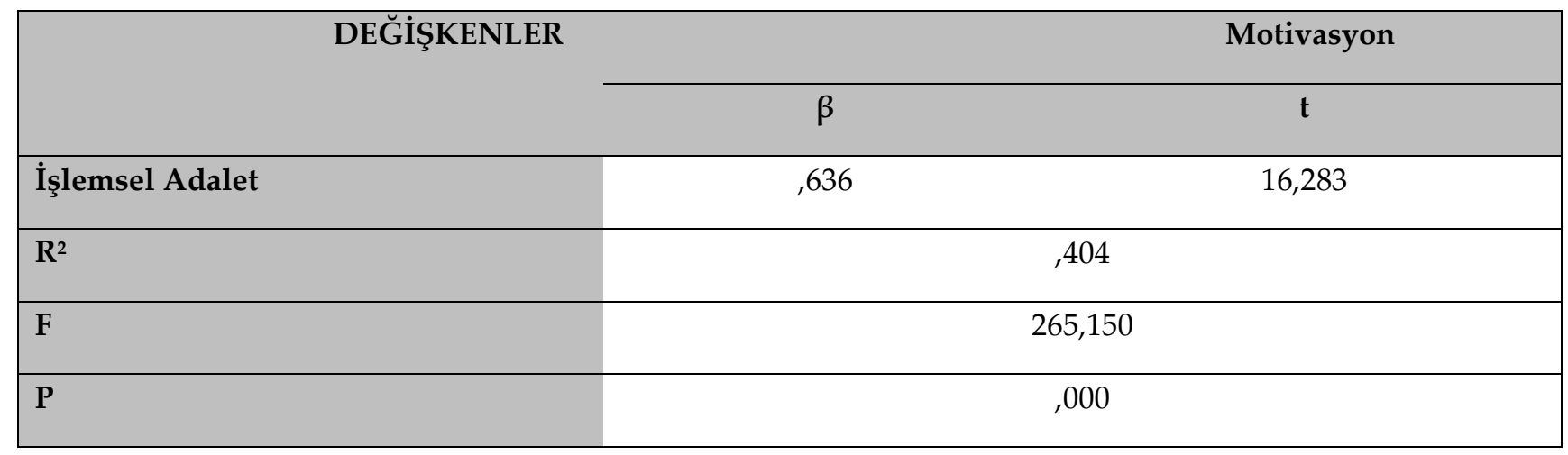

* $\mathrm{p}<0,05$ anlamlı ilişki

Tablo 3'e bakıldığında, $\mathrm{R}^{2}=, 404 ; \mathrm{F}=265,150 ; \mathrm{p}=, 000$ olduğu için regresyon modelinin anlamlı olduğu ve işlemsel adalet algısının motivasyon üzerinde \%40,4 etkiye sahip olduğu görülmektedir. Bunun yanında işlemsel adaletin $(\beta=, 636 ; \mathrm{t}=16,283 ; \mathrm{p}=, 000)$ motivasyon üzerinde anlamlı ve pozitif bir etkisinin gözlenmesinden dolayı yeterli kanıtla desteklenmiştir.

Hı: Etkileşimsel adalet algısının işgören motivasyonu üzerinde etkisi vardır. 
G. Uysal - A. Tayfun 11/1 (2019) 597-611

Tablo 4. Etkileşimsel Adalet Algısının İşgören Motivasyonu Üzerine Etkisi

\begin{tabular}{|c|c|c|c|}
\hline DEĞİŞKENLER & \multicolumn{3}{|c|}{ Motivasyon } \\
\hline & $\beta$ & & $t$ \\
\hline Etkileşimsel Adalet & 684 & & 18,557 \\
\hline $\mathbf{R}^{2}$ & \multicolumn{3}{|c|}{,468 } \\
\hline $\mathbf{F}$ & \multicolumn{3}{|c|}{344,380} \\
\hline $\mathbf{P}$ & \multicolumn{3}{|c|}{,000 } \\
\hline
\end{tabular}

${ }^{*} \mathrm{p}<0,05$ anlamlı ilişki

Tablo 4 'te görüldüğü gibi, $\mathrm{R}^{2}=, 468 ; \mathrm{F}=344,380 ; \mathrm{p}=, 000$ olduğu için regresyon modeli istatistiksel olarak anlamlıdır. Etkileşimsel adalet algısı motivasyon üzerinde \%46,8 etkiye sahiptir. Ayrıca etkileşimsel adalet, motivasyon üzerinde bir etkiye sahiptir. $t$ değerine bakıldığında ilişkinin istatiksel olarak anlamlı ve pozitif olduğu görülmektedir ( $\beta=, 684 ; \mathrm{t}=18,557 ; \mathrm{p}=, 000)$. Buradan hareketle $\mathrm{H}_{1 c}$ yeterli kanıtla desteklenmiştir.

$\mathbf{H}_{2}$ : Örgütsel adalet algısının işgörenlerin işten ayrılma niyeti üzerinde etkisi vardır.

$\mathbf{H}_{2 a}$ : Dağıtım adalet algısının işgörenlerin işten ayrılma niyeti üzerinde etkisi vardır.

Tablo 5. Dağıtımsal Adalet Algısının İşgörenlerin İşten Ayrılma Niyeti Üzerine Etkisi

\begin{tabular}{|c|c|c|}
\hline \multirow{2}{*}{ DEĞISSKENLER } & \multicolumn{2}{|c|}{ İşten Ayrılma Niyeti } \\
\hline & $\beta$ & $\mathbf{t}$ \\
\hline Dağıtımsal Adalet &,- 183 & $-3,672$ \\
\hline $\mathbf{R}^{2}$ & \multicolumn{2}{|c|}{,033 } \\
\hline $\mathbf{F}$ & \multicolumn{2}{|c|}{13,484} \\
\hline $\mathbf{P}$ & \multicolumn{2}{|c|}{,000 } \\
\hline
\end{tabular}

${ }^{*} \mathrm{p}<0,05$ anlamlı ilişki

Tablo 5'te görüldüğ̈̈ üzere, $R^{2}=, 033 ; F=13,484 ; p=, 000$ olduğu için regresyon modelinin anlamlı olduğu ve dağıtımsal adalet algısının işten ayrılma niyeti üzerinde \%3,3 etkiye sahip olduğu ifade edilmektedir. Bunun yanında dağıtımsal adaletin $(\beta=-, 183 ; \mathrm{t}=-3,672 ; \mathrm{p}=, 000)$ işten ayrılma niyeti üzerinde anlamlı ve negatif bir etkisinin gözlenmesinden dolayı $\mathrm{H}_{2 a}$ yeterli kanıtla desteklenmiştir.

$\mathbf{H}_{2 b}$ :İşlemsel adalet algısının işgörenlerin işten ayrılma niyeti üzerinde etkisi vardır.

Tablo 6. İşlemsel Adalet Algısının İşgörenlerin İşten Ayrılma Niyeti Üzerine Etkisi

\begin{tabular}{|c|c|c|c|}
\hline & \multirow[t]{2}{*}{ DEĞİŞKENLER } & \multicolumn{2}{|c|}{ İşten Ayrılma Niyeti } \\
\hline & & $\beta$ & $\mathbf{t}$ \\
\hline İşlemsel Adalet & &,- 200 & $-4,038$ \\
\hline $\mathbf{R}^{2}$ & & \multicolumn{2}{|c|}{,040 } \\
\hline $\mathbf{F}$ & & \multicolumn{2}{|c|}{16,309} \\
\hline $\mathbf{P}$ & & \multicolumn{2}{|c|}{,000 } \\
\hline
\end{tabular}

${ }^{*} \mathrm{p}<0,05$ anlamlı ilişki 
Tablo 6'da görüldüğ ü gibi, $\mathrm{R}^{2}=, 040 ; \mathrm{F}=16,309 ; \mathrm{p}=, 000$ olduğu için regresyon modeli istatistiksel olarak anlamlıdır. İşlemsel adalet algısı işten ayrılma niyeti üzerinde \%4,0 etkiye sahiptir. Ayrıca işlemsel adaletin işten ayrılma niyeti üzerinde bir etkisi vardır. $t$ değerine bakıldığında ilişkinin istatiksel olarak anlamlı ve negatif olduğu görülmektedir $(\beta=-, 200 ; \mathrm{t}=-4,038 ; \mathrm{p}=, 000)$. Bu açıklamalar neticesinde $\mathrm{H}_{2 b}$ yeterli kanıtla desteklenmiştir.

$\mathbf{H}_{2 c \text { : }}$ Etkileşimsel adalet algısının işgörenlerin işten ayrılma niyeti üzerinde etkisi vardır.

Tablo 7. Etkileşimsel Adalet Algısının İşten Ayrılma Niyeti Üzerine Etkisi

\begin{tabular}{|lcc|}
\hline DEĞİŞKENLER & \multicolumn{2}{c|}{ İşten Ayrılma Niyeti } \\
\cline { 2 - 3 } & $\boldsymbol{B}$ & $\mathbf{t}$ \\
\hline Etkileşimsel Adalet &,- 160 & $-3,204$ \\
\hline $\mathbf{R}^{2}$ & & \\
\hline $\mathbf{F}$ & \multicolumn{2}{c|}{1026} \\
\hline $\mathbf{P}$ &, 001 \\
\hline
\end{tabular}

${ }^{*} \mathrm{p}<0,05$ anlamlı ilişki

Tablo 7'de görüldüğü gibi, $\mathrm{R}^{2}=, 026 ; \mathrm{F}=10,265 ; \mathrm{p}=, 001$ olduğu için regresyon modeli istatistiksel olarak anlamlıdır. Etkileşimsel adalet algısı işten ayrılma niyeti üzerinde \%2,6 etkiye sahiptir. Ayrıca etkileşimsel adaletin, işten ayrılma niyeti üzerinde etkisi vardır. Bu etkinin, $\mathrm{t}$ değerine bakıldığında istatiksel olarak anlamlı ve negatif olduğu görülmektedir $(\beta=,-160 ; t=-3,204 ; p=, 001)$. Buradan hareketle $H_{1 c}$ yeterli kanitla desteklenmiştir.

H3: İşgören motivasyonu ile işten ayrılma niyeti arasında anlamlı bir ilişki vardır.

Tablo 8. İşgören Motivasyonu İle İşten Ayrılma Niyeti Arasındaki İlişski

\begin{tabular}{|lccc|}
\hline \multirow{2}{*}{ DEĞİŞKENLER } & \multicolumn{3}{c|}{ İşten Ayrılma Niyeti } \\
\cline { 2 - 4 } & $\mathbf{n}$ & $\mathbf{r}$ & $\mathbf{p}$ \\
\hline Motivasyon & 393 &,- 121 &, 016 \\
\hline
\end{tabular}

${ }^{*} \mathrm{p}<0,05$ anlamlı ilişki

Tablo 8'e göre $r=-, 121$ ile işgörenlerin motivasyon ve işten ayrılma niyetleri arasında düşük düzeyde, negatif ve anlamlı $(\mathrm{p}<0,05)$ bir ilişki olduğu söylenebilir. Motivasyon düzeyi arttıkça işten ayrılma niyeti azalmaktadır. Bu durumda $\mathrm{H}_{3}$ yeterli kanıtla desteklenmiştir.

\section{Sonuç ve Öneriler}

Hizmet sektörünün vazgeçilmez işletmeleri olan oteller, bu sektörünün can damarlarındandır ve insan unsuru bu işletmelerin merkezinde yer almaktadır. Emek yoğun özellik gösteren bu işletmelerde insan kaynakları uygulamalarının önemi daha da artmaktadır. Buna eşdeğer olarak, bu örgütlerin başarıya ulaşmaları için insan kaynaklarına verilmesi gereken önem de hızla artmaktadır. Özellikle yöneticilerin işgörenlerine değer vermeleri, onları kurumlarının sadece işgören olarak değil, aynı zamanda bir ortağı olarak görmeleri, işgörenleri arasında adil uygulamalara yer vermeleri işgörenlerin örgütlerine dair adalet değerlendirmelerini güçlendireceğinden, işgörenlerin motivasyon düzeyleri artacak ve işten ayrılma niyetleri de bu bağlamda azalacaktır. Kişiler çalıştıkları örgütlerde adaletsiz davranıldığı yönünde değerlendirmelere kapıldıklarında olumsuz duygulara kapılarak hem örgütleri hem de kendileri için olumsuz davranışlar sergileyebileceğinden işletmeler işgörenlerini memnun etmek ve işgücü devrini en aza indirmek için örgütlerindeki adalet değerlendirmelerini en yüksek seviyede tutmaya çalışmaktadırlar.

Hipotezlerin test sonuçları incelendiğinde, örgütsel adalet algısı boyutlarının motivasyon üzerinde anlamlı bir etkiye sahip olduğu görülmektedir. Katılımciların örgütsel adalet alg1sı olumlu olduğunda motivasyon düzeylerinin arttı̆̆ı, aksi takdirde motivasyon düzeylerinin düştüğü tespit edilmiştir. Bu boyutlardan en fazla etkiye sahip olan \%46,4 ile etkileşimsel adalettir. Etkileşimsel adaleti, \%40,4 ile işlemsel adalet ve \%29,6 
ile dağıtımsal adalet takip etmektedir. Bu sonuçlardan anlaşılacağı üzere örgütsel adalet boyutları arasında; iletişimin, ilginin, saygı ve sevginin etkili olduğu etkileşimsel adaletin motivasyon üzerinde önemli bir etkisi olduğu görülmektedir. Bu durum literatürde ki diğer çalışmalarla desteklenmektedir. Acar (2011) yaptığ1 araştırmada örgütsel adaletin üç alt boyutunun da yüksek düzeyde algılandığını ve etkileşimsel adaletin daha ön plana çıtığını saptamıştır (Acar, 2011). Abbasoğlu (2015) bir devlet hastanesi üzerinde yaptığı çalışmada işgörenlerin etkileşimsel adalet algılarının, örgütsel adaletin diğer boyutları olan dağıtımsal ve işlemsel adalet boyutlarına göre daha yüksek olduğu tespit edilmiştir. Oral (2012) 221 sağlık çalışanları üzerinde gerçekleştirdiği çalışmasında benzer sonuçları elde etmiş, etkileşimsel adalet algısı dağıtımsal ve işlemsel adalet algısına göre yüksek algılanmıştır (Oral, 2012). İren (2015) İlkokul öğretmenleri üzerinde yaptığı araştırma değerlendirildiğinde örgütsel adaletin alt boyutları üzerinde en yüksek düzeyi etkileşimsel adalet algısı oluşturmaktadır (İren, 2015). Etkileşimsel adaletin yüksek olduğu durumlarda, işgörenler açısından dağıtımsal ve prosedürel adaletin öneminin azaldığını ve kesişimin anlamlı olmadığı belirtilmektedir. Ulaşılan bulgular neticesinde, işverenlerin işgörenlere karşı duyarlı, ilgili, saygılı ve itibarlı davranışlar sergilediklerinde, işgörenlerin adaletsiz ücret dağılımını veya adaletsiz süreçleri bir nebze görmezden gelmeleri, daha fazla hoşgörülü olma yönünde hareket ettikleri, şeklinde yorumlanmıştır (Skarlicki ve Folger, 1997).

Örgütsel adalet algısı boyutlarının işten ayrılma niyeti üzerine etkisinin sonuçlarına bakıldığında, boyutlar arasında en fazla etkiye \%4,0 ile işlemsel adalet, \%3,3 ile dağıtımsal adalet ve \%2,6 ile etkileşimsel adalet algısının etkili olduğu görülmektedir. Çalışmadaki katılımcılara göre işten ayrılma niyeti üzerinde en fazla etkiye; karar alma sürecine katılmayı, bu süreçte tarafsız olmayı ve yöntemlerin adil bir şekilde algılanması ile ilgilenen işlemsel adalet algısı sahiptir. Adaletin sağlanması durumunda işgörenlerin işten ayrılmaya niyetlerinin azalacağı belirgindir. Bu durumda yöneticiler açısından örgüt ortamında adaletin tesis edilmesi önem arz etmektedir. Adaletin sağlandığı bir iş ortamında işgörenler işten ayrılma niyetinde olmayacakları için asıl işlerine ve örgüte daha fazla yoğunlaşacaklardır. Araştırmada elde edilen bulgular, konu ile ilgili daha önce yürütülen çalışmaların bulguları ile örtüşmektedir. Sökmen, Bilsel ve Erbil (2013) bankacılık sektöründe yaptıkları çalışma sonuçlarına göre işgörenlerin, işletmelerinin adaletli davrandığına ilişkin inancının, işgörenlerin görevlerinin gereğini yerine getirmede belirleyici bir rolü olduğu bulunmaktadır (Sökmen, Bilsel ve Erbil, 2013). Sunar (2016) bankacılık sektörüne yönelik yaptığı çalışmada işletme yöneticilerinin işgörenlerinin beklentilerini gözetmesi, kendilerine, yaklaşımlarına ve uygulamalarına ilişkin değerlendirmeleri yönetmesinin; işletmenin hedeflerine ulaşması açısından önem arz ettiği ve örgütsel adaletin pozitif çıktıları işletmeye anlamlı katkılar sağlayacağı sonucuna ulaşılmıştır (Sunar, 2016). Buradan hareketle işletme yöneticileri karı arttırmak, işletme hedeflerine ulaşmak için örgüt içerisinde adaleti sağlamalıdırlar aksi takdirde yöneticiler ve işletme zarara uğrayacaktır. Adaletin tesisi işgörenler üzerinde olumlu davranışlar geliştirilmesinde etkili olacağı düşünülmektedir. Çünkü adaletin burada bir tetik etkisi yarattığ1 söylenebilir.

Motivasyon ve işten ayrılma niyeti arasındaki ilişkiye bakıldığında düşük düzeyde, negatif yönlü anlamlı bir ilişkisinin olduğu sonucuna varılmıştır. Motivasyon düzeyi yüksek olan işgörenler işten ayrılma niyeti içerisinde olmamaktadırlar. Aksi halde işten ayrılma niyetinin artmakta ve işgörenlerin asıl faaliyetlerine yoğunlaşamadıkları ifade edilebilir. Bu durum literatürdeki çalışmalarla da benzerdir. Ünsar (2011) yaptı̆̆ı çalışmanın araştırma bulguları genel olarak değerlendirildiğinde motive olmuş bir iş görenin işten ayrılma eğiliminin düşük, tersi durumunda ise yüksek olduğu belirlenmiştir (Ünsar, 2011). Yıldız, Savcı ve Kapu (2014) araştırmalarında motive edici faktörlerin işten ayrılma niyetini negatif yönde etkilediği sonucuna varmışlardır (Yıldız, Savcı ve Kapu, 2014).

Araştırma sonucunda elde edilen veriler ışığında şu önerilerde bulunulabilir:

- Çalışma sonuçlarında da yer aldığı üzere örgütsel adalet boyutları motivasyonu ve işten ayrılma niyetini etkilediği sonuçlarına ulaşılmıştır. Motivasyon düzeylerinin düşmemesi ve işten ayrılma niyetlerinin artmaması için otel işletmeleri tarafından örgütsel adaletsizliğe neden olan unsurların belirlenmesi ve gerekli tedbirlerin alınması işletmeler için yararlı olacaktır.

- Mevcut işgörenlerin işletmelerde tutulma maliyeti yeni eleman bulma ve istihdam etme maliyetinden daha düşük olduğu için işletmelerin mevcut işgörenleri kaybetmemesi büyük önem arz etmektedir. Bu bağlamda işgörenlerin örgütsel adalet algısının ve motivasyon düzeyinin yüksek tutulması işten ayrılma 


$$
\text { G. Uysal - A. Tayfun 11/1 (2019) 597-611 }
$$

niyetinin artmaması için otel işletmeleri tarafından gerekli tedbirlerin alınmasının işletmeler için yararlı olacaktır.

- İşgörenlerin örgütsel adalet algıları, motivasyon ve işten ayrılma niyetlerinin belirli aralıklarla kontrol edilip artış ya da azalışların nedenleri hakkında detaylı araştırmaların yapılması işletmeler için ileride doğabilecek sorunların önüne geçilmesi noktasında son derece önemlidir.

- İşletme yöneticilerine örgütsel adalet, motivasyon, işten ayrılma niyeti kavramlarına ilişkin kuramsal ve uygulamaya yönelik bilgilerin verilmesi amacı ile çeşitli hizmet içi eğitim faaliyetler düzenlenmelidir.

- İşletme yöneticilerinin örgütle ilgili kurallara sadık kalıp keyfi uygulamalardan kaçınarak bu kuralları herkese eşit uygulamaları, işgörenlere verilen ödül ve ceza dağıtımı gibi uygulamalarda hak esasına dayalı olarak adil davranmaları, işgörenleri karar verme sürecine dahil etmeleri işgörenlerin örgütsel adalet algıların arttıracaktır.

- Son olarak, örgütsel adalet algısının motivasyon ve işten ayrılma niyeti üzerine etkisi farklı bölgelerdeki otel işletmelerinde veya Türkiye geneli tüm otel işletmeleri dikkate alınarak araştırma gerçekleştirilebilir. Ayrıca, konu sadece otel işletmeleri ile sinırlandırılmamalı, turizm hizmeti veren diğer işletmeleri ve turizm dışındaki sektörleri kapsayan geniş boyutlu araştırmalar yapılarak daha farklı sonuçlara ulaşılabilir.

\section{Kaynakça}

Abbasoğlu, Ş. (2015). İşgörenlerde Örgütsel Adalet Algısı ve Örgütsel Adaletin Çalışanların İş Motivasyonu Üzerindeki Etkisi "Bir Devlet Hastanesi Örneği". Yüksek Lisans Tezi, Atılım Üniversitesi Sosyal Bilimler Enstitüsü, Ankara.

Acar, G. (2011). Okul Yöneticilerinin Etik Liderlik Davranışlarının Beden Eğitimi Öğretmenlerinin Örgütsel Adalet ve Motivasyon Düzeyleriyle İlişkisi, Doktora Tezi, Gazi Üniversitesi Eğitim Bilimleri Enstitüsü, Ankara.

Ağaoğlu, O. K. (1992). "İşücünü Verimli Kullanma Tekniklerinin Turizm Sektörüne Uygulanması". Verimlilik Dergisi, Milli Prodüktivite Yayını No: 457, Ankara.

Akbudak, A. (2013). Konaklama İşletmelerinde Çalışanların İş Tatmini, Motivasyonları ve Demografik Faktörleri Arasındaki İlişkinin Belirlenmesi; Bir Oteller Grubu Bünyesindeki 5 Yıldızlı Zincir Otel İşletmelerine Yönelik Bir Uygulama, Yüksek Lisans Tezi, Akdeniz Üniversitesi Sosyal Bilimler Enstitüsü, Antalya.

Ambrose, M. L. (2000). “Drug Testing and Procedural Fairness: The Influence of Situational Variables". Social Justice Research, 13(1), 25-40.

Arslantaş, C.C ve Dursun M. (2008). “Etik Liderlik Davranışının Yöneticiye Duyulan Güven Ve Psikolojik Güçlendirme Üzerindeki Etkisinde Etkileşim Adaletinin Dolaylı Rolü". Anadolu Üniversitesi Sosyal Bilimler Dergisi, 8 (1). 111-127

Atalay, C. (2010). Giderler; Örgütsel Adalet, Örgütsel Davranışta Güncel Konular, Ekin Basım Yayın, Bursa.

Avcl, N. ve Küçükusta, D. (2009). “Konaklama İşletmelerinde Örgütsel Öğrenme, Örgütsel Bağl1lık Ve İşten Ayrılma Eğilimi Arasındaki İlişki". Anatolia: Turizm Araştırmaları Dergisi, 20(1), 33-44.

Aykut, S. (2007). Örgütsel Adalet, Birey -Örgüt Uyumu İle Çalışanların İşle İlgili Tutumları (Pendik İlçesi Örneği), Yayınlanmamış Yüksek Lisans Tezi, Yeditepe Üniversitesi Sosyal Bilimler Enstitüsü, , İstanbul.

Bakan, İ. (2011). Örgütsel Bağlılık. Ankara: Gazi Kitabevi, 12-253.

Berber, A. (2010). Çalışanların Örgütsel Adalet Algılamaları ile Örgütsel Vatandaşlık Davranışları Arasındaki İlişkinin İncelenmesine Yönelik Bir Uygulama. Yüksek Lisans Tezi, Yıldız Teknik Üniversitesi, İstanbul.

Beugre, C.D. ve Baron, R.A. (2001). "Perceptionsof Systemic Justice: The Effects of Distributive, Procedural, and Interactional Justice". Journal of Applied Social Psychology, 31 (2), 324-339. 


$$
\text { G. Uysal - A. Tayfun 11/1 (2019) 597-611 }
$$

Bilsel, M. A. (2013). Örgütsel Adalet Algısının Banka Çalışanlarının Performans ve Motivasyonlarına etkisi: Bir Araştırma, Yayımlanmamış Yüksek Lisans Tezi, Gazi Üniversitesi Sosyal Bilimler Enstitüsü, Ankara, 2013.

Cihangiroğlu, N. ve Yılmaz, A. (2010). "Çalışanların Örgütsel Adalet Algısının Örgütler için Önemi”. Selçuk Üniversitesi İktisadi ve İdari Bilimler Fakültesi Sosyal ve Ekonomik Araştırmalar Dergisi, 13(19), 195213.

Cremer, D. D. (2005). "Procedural and Distributive Justice Effects Moderated By Organizational Identification". Journal of Managerial Psychology, 20(1), 4- 13.

Çă̆, A. (2011). Algılanan Örgütsel Adaletin, Örgütsel Sinizme ve İşten Ayrılma Niyetine Etkisinin Belirlenmesine Yönelik Bir Araştırma. Yüksek Lisans Tezi, Afyon Kocatepe Üniversitesi Sosyal Bilimler Enstitüsü, Afyonkarahisar.

Çekmecelioğlu, H. G. (2005). “Örgüt İkliminin İş Tatmini ve İşten Ayrılma Niyeti Üzerindeki Etkisi: Bir Araştırma". C.Ü. İktisadi ve İdari Bilimler Dergisi, 6(2), 23-39.

Çelik, A. (2011). Profesyonel Futbol Kulüp Yöneticilerinin Çatışmayı Yönetme Stratejilerinin Mükemmeliyetçilik Özellikleri ve Motivasyon Düzeyleriyle İlişkisi, Doktora Tezi, Gazi Üniversitesi Sağlık Bilimleri Enstitüsü, Ankara.

Çolak, M. ve Erdost, H.E. (2004). “Organizational Justice: A Review of the Literature and Some Suggestions For Future Research". Hacettepe Üniversitesi İktisadi ve İdari Bilimler Fakültesi Dergisi, 22(2), 5184.

Demirel, G. (2012). Örgütsel Adalet Algısının İş Bırakma Eğilimi Üzerine Etkisi: Antalya İli 4 ve 5 Yıldızlı Otel İşletmeleri Üzerine Bir Araştırma, Yüksek Lisans Tezi, Çanakkale Onsekiz Mart Üniversitesi Sosyal Bilimler Enstitüsü, Çanakkale.

Dinç A. ve Ceylan A. (2008). “Kaçak Elektrik Kullanımıyla İlgili İdare Çalışanı Tutumunun Örgütsel Adalet ve İş Memnuniyeti ile İlişkisi, Çalışma Gruplarına Göre Farklılıklar". Cumhuriyet Üniversitesi İktisadi ve İdari Bilimler Dergisi, 9 (2), 13.

Efil, İ. (2010). İşletmelerde Yönetim ve Organizasyon. 11.Baskı. Dora Yayınevi, Bursa.

Erbil, S. (2013). Otel İşletmelerinde Çalışanların Örgütsel Sinizm Algılarının İşten Ayrılma Niyetine Etkisi, Yüksek Lisans Tezi, Adnan Menderes Üniversitesi Sosyal Bilimler Enstitüsü, Aydın.

Erdem, B. (2002). Otel İşletmelerinde İnsan Kaynakları Yönetimi Açısından Personel Bulma ve Seçme Süreci (Örnek Bir Uygulama), Yüksek Lisans Tezi, Balıkesir Üniversitesi Sosyal Bilimler Enstitüsü, Balıkesir.

Gökkaya, C. (2012). İşgörenlerin Motivasyon Düzeyleri İle Müşterilerin Memnuniyet Algılarının Belirlenmesi: Zonguldak Ağız ve Diş Sağlığı Merkezi'nde Bir Uygulama, Yüksek Lisans Tezi, Gazi Üniversitesi Eğitim Bilimleri Enstitüsü, Ankara.

Greenberg, J. (1990). “Organizational Justice: Yesterday, Today and Tomorrow”. Journal of Management, 16(2), $399-432$.

Irak, U. D. (2004). “Örgütsel Adalet: Ortaya Çıkışı, Kurumsal Yaklaşımlar ve Bugünkü Durumu”. Türk Psikoloji Yazıları, 7(13), 25-43.

İçerli, L. (2010). “Örgütsel Adalet: Kuramsal Bir Yaklaşım”. Girişimcilik ve Kalkınma Dergisi, 5 (1), 68 - 92.

İren, S. (2015). İlkokullarda Görev Yapan Öğretmenlerin Örgütsel Adalet Algıları ile Mesleki Motivasyon Düzeyleri Arasındaki İlişkinin İncelenmesi: Tuzla Örneği, Yüksek Lisans Tezi, İstanbul Üniversitesi Sosyal Bilimler Enstitüsü, İstanbul.

Karaboğa, M.(2007). Avcılar İlçesi Ortaöğretim Kurumları Yöneticilerinin Motivasyonlarının Çalışan (Öğretmen) Motivasyonu Üzerine Etkisi, Yüksek Lisans Tezi, Beykent Üniversitesi, İstanbul.

Karademir, T. ve Çoban, B. (2010). “Sporun Yönetsel Yapısında Örgütsel Adalet Kuramına Bakış”. Niğde Üniversitesi Beden Eğitimi ve Spor Bilimleri Dergisi, 4 (1), 48-63. 


$$
\text { G. Uysal - A. Tayfun 11/1 (2019) 597-611 }
$$

Kaya, B. (2012). Algılanan Örgütsel Destek Düzeyinin ve Çalışanların Kariyer Tatmininin İşten Ayrılma Niyeti Üzerindeki Etkileri: Konaklama İşletmelerinde Bir Uygulama, Yüksek Lisans Tezi, Akdeniz Üniversitesi Sosyal Bilimler Enstitüsü, Antalya.

Kaya, H. ve Abdioğlu, H. (2010). “Çalışanların Örgütten Ayrılma Eğilimleri Üzerine Bir Araştırma”. Amme İdaresi Dergisi, 43 (4), 129-165.

Kılıçlar, A. (2011). "Yöneticiye Duyulan Güven ile Örgütsel Adalet İlişkisinin Öğretmenler Açısından İncelenmesi". İşletme Araştırmaları Dergisi, 3(3), 2336.

Koç, H. ve Topaloğlu, M. (2012). Yönetim Bilimi. 2. Basım. Seçkin Yayınevi, Ankara.

Koçel, T. (2011). İşletme Yöneticiliği. 13. Basım. Beta Yayınevi İstanbul.

Küçükahmet, L. (2001). Sınıf Yönetiminde Yeni Yaklaşımlar, Nobel Yayınları, Ankara.

Laçinoğlu, Z. (2010). İlköğretim Okulu Öğretmenlerinin Örgütsel Adalet Algıları ile Bazı Örgütsel Davranışlar Arasındaki İlişki (Sakarya İli Örneği), Yüksek Lisans Tezi, Sakarya Üniversitesi Sosyal Bilimler Enstitüsü, Sakarya.

Lambert, E. G. (2006). "I Want to Leave: A Test of A Model of Turnover Intent Among Correctional Staff". Applied Psychology in Criminal Justice, 2 (1), 57-83.

Lambert, G. H., Hogan, L. H. ve Griffin M. L. (2007). “The Impact of Distributive and Procedural Justice on Correctional Staff Job Stress, Job Satisfaction and Organizational Commitment". Journal of Criminal Justice, 35, 644-656.

Moon, H., Kamdar, D., Mayer, D. M. ve Takeuchi, R. (2008). "Me or We? The Role of Personality and Justice as Other-Centered Antecedents to Innovative Citizenship Behaviors Within Organizations". Journal of Applied Psychology, 93(1), 84-94.

Moorman, R H. (1991), "Relationship Between Organizational Justice and Organizational Citizenship Behaviors: Do Fairness Perceptions Influence Employee Citizenship?", Journal of AppliedPsychology, $76(6), 845-855$.

Niehoff, B.P. ve Moormon, R.H. (1993). "Justice As A Mediator of The Relationship Between Methods of Monitoring and Organizational Citizenship Behavior". Academy of Management Journal, 36(3), 527556.

Oral, N. (2012). Örgütsel Adalet Algısı ile Örgütsel Vatandaşlık Davranışı İlişkisi: Sağlık Örgütünde Bir Uygulama, Yayımlanmamış Yüksek Lisans Tezi, Eskişehir Anadolu Üniversitesi Sosyal Bilimler Enstitüsü, Eskişehir.

Öğüt, A., Akgemici, T. Ve Demirsel, M.T. (2004). “Stratejik İnsan Kaynakları Yönetimi Bağlamında Örgütlerde İşgören Motivasyonu Süreci”. Selçuk Üniversitesi Sosyal Bilimler Dergisi, 12, 277-29.

Özcan, E., Vardarlıer, P., Karabay, M., Konakay, G. ve Çetin, C. (2012) “Liderliğin Örgütsel Vatandaşlık Davranışı ve İşten Ayrılma Niyeti Üzerindeki Etkisinde Güvenin Rolü", 10 (37), 1-13.

Özdevecioğlu, M. (2004). “Duygusal Olaylar Teorisi Çerçevesinde Pozitif ve Negatif Duygusallı̆̆ın Algılanan Örgütsel Adalet Üzerindeki Etkilerini Belirlemeye Yönelik Bir Araştırma". Ankara Üniversitesi Siyasal Bilimler Fakültesi Dergisi, 59(3), 181-202.

Özen, J. (2002). "Adalet Kuramlarının Gelişimi ve Örgütsel Adalet Türleri”. Hukuk Felsefesi ve Sosyolojisi Arşivi, 5, 107-117.

Porter, L. W., Steers, R. M., and Boulian, P. V. (1973). “Organizational Commitment, Job Satisfactıon and Turnover Among Psyciatric Technicians". Technical Report, (16), 1-21.

Serinkan, C. (2008). Liderlik ve Motivasyon. 1 Baskı. Nobel Yayınları, Ankara.

Skarlicki, D.P. and Folger, R. (1997). "Retaliation in the Workplace: The Roles of Distributive, Procedural, and Interactional Justice". Journal of Applied Psychology, 82(3), 434-443.

Sökmen, A. (2010). Yönetim ve Organizasyon, Detay Yayıncllık, Ankara. 
G. Uysal - A. Tayfun 11/1 (2019) 597-611

Sökmen, A., Bilsel, M.A. ve Erbil, C. (2013). “Örgütsel Adaletin Çalışan Motivasyonu ve Performansı Üzerindeki Etkisi: Bankacılık Sektöründe Bir Araştırma". Gazi Üniversitesi, İktisadi ve İdari Bilimler Fakültesi Dergisi. 15 (1), 43-62.

Sunar, S. (2016). Örgütsel Adaletin İş Tatmini ve İşten Ayrılma Niyeti Üzerindeki Etkisine Yönelik Bankacılık Sektöründe Bir Uygulama, Yüksek Lisans Tezi, Bahçeşehir Üniversitesi Sosyal Bilimler Enstitüsü, İstanbul.

Taşkıran, E. (2011). Liderlik ve Örgütsel Sessizlik Arasındaki Etkileşim, Örgütsel Adaletin Rolü, Beta Basım Yayım, İstanbul, 2011.

Tett, R. P. and Meyer, J. P. (1993). “Job Satisfaction, Organizational Commitment, Turnover Intention and Turnover: Path Analyses Based On Meta- Analytic Findings". Personnel Psychology, 46, 259-293.

Ünsar, A.S. (2011). “Motivasyonunun İşten Ayrılma Eğilimine Etkisi: Bir Alan Araştırması”. Akademik Bakış Dergisi, 25, 1-15.

Yavuz, E. (2010). “Kamu ve Özel Sektör Çalışanlarının Örgütsel Adalet Algılamaları Üzerine Bir Karşılaştırma Çalışması". Doğuş Üniversitesi Dergisi, 11(2), 302-312.

Yazıcıoğlu, Y. ve Erdoğan, S. (2004). Spss Uygulamalı Bilimsel Araştırma Yöntemleri. Detay Yayıncılık, Ankara.

Yıldırım, F. (2006). “İş Doyumu İle Örgütsel Adalet İlişkisi”. Ankara Üniversitesi SBF Dergisi, 62 (1), 254-280.

Yıldız, S. (2008). Örgüt Kültürünün İşten Ayrılma Eğilimi ve Çalışan Verimliliği Üzerindeki Etkisi: Bir Ara Değişken Olarak Örgütsel Destek Algısı. Yayımlanmamış Yüksek Lisans Tezi, Abant İzzet Baysal Üniversitesi Sosyal Bilimler Enstitüsü, Bolu.

Yıldız, S., Savcı, G. ve Kapu, H. (2014). "Motive Edici Faktörlerin Çalışanların İş Performansına ve İşten Ayrılma Niyetine Etkisi". Celal Bayar Üniversitesi İktisadi İdari Bilimler Fakültesi Dergisi, 21 (1), 233249.

Yürür, S. (2005). Ödüllendirme Sistemleri ile Örgütsel Adalet Arasındaki İlişkilerin Analizi ve Bir Uygulama, Yüksek Lisans Tezi, Uludağ Üniversitesi Sosyal Bilimler Enstitüsü, Bursa. 